\title{
Long-term following-up of viability of spleen autotransplants in the Beagle canine model
}

\author{
Avaliação em longo prazo da viabilidade do autotransplante de baço em cães Beagle
}

\author{
Erika Sajtos $^{\mathrm{I}}$, Anita Balint ${ }^{\mathrm{II}}$, Endre Brath ${ }^{\mathrm{III}}$, Norbert Nemeth ${ }^{\mathrm{IV}}$, Katalin Peto ${ }^{\mathrm{V}}$, Judit Kovacs ${ }^{\mathrm{VI}}$, Laszlo Galuska ${ }^{\mathrm{VII}}$, Jozsef Varga ${ }^{\mathrm{VIII}}$, \\ Zoltan Fodor $^{\mathrm{IX}}$, Istvan Furka ${ }^{\mathrm{X}}$, Iren Miko ${ }^{\mathrm{XI}}$
}

${ }^{I} \mathrm{MD}$, Full time PhD student, Department of Operative Techniques and Surgical Research, Department of Surgery, Medical and Health Science Center, University of Debrecen, Debrecen, Hungary. Involved with technical procedures, analysis and interpretation of data, manuscript writing.

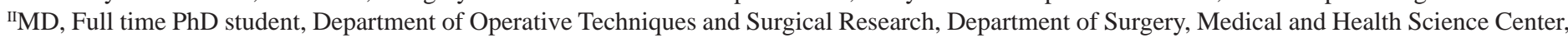
University of Debrecen, Debrecen, Hungary. Taking part in evaluating results.

"IMD, PhD, Assistant Lecturer, Department of Operative Techniques and Surgical Research, Department of Surgery, Medical and Health Science Center, University of Debrecen, Debrecen, Hungary. Helped with technical procedures and acquisition of data.

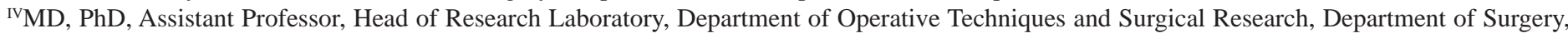
Medical and Health Science Center, University of Debrecen, Debrecen, Hungary. Helped with technical procedures, collection and processing of study informations, manuscript writing.

${ }^{\vee}$ MD, PhD, Assistant Professor, Department of Operative Techniques and Surgical Research, Department of Surgery, Medical and Health Science Center, University of Debrecen, Debrecen, Hungary. Helped surgical interventions and acquisition of data.

${ }^{\mathrm{VI}} \mathrm{MD}$, PhD, Associate Professor, Chief Doctor, Department of Pathology, Semmelweis Hospital, Miskolc, Hungary. Histological examinations and acquisition of data.

${ }^{V I I} \mathrm{MD}, \mathrm{PhD}$, DSc, Full Professor, Institute of Nuclear Medicine, Medical and Health Science Center, University of Debrecen, Debrecen, Hungary. Performing functional imaging investigations and evaluating results.

${ }^{\mathrm{VIII}} \mathrm{PhD}$, Associate Professor, Head of the Institute, Institute of Nuclear Medicine, Medical and Health Science Center, University of Debrecen, Debrecen, Hungary. Performing functional imaging investigations and evaluating results.

${ }^{\text {Ix}}$ PharmD, Assistant Lecturer, Institute of Nuclear Medicine, Medical and Health Science Center, University of Debrecen, Debrecen, Hungary. Performing functional imaging investigations.

${ }^{\mathrm{x}} \mathrm{MD}, \mathrm{PhD}$, DSc, Full Professor, Head of Microsurgical Educational and Training Center, Department of Operative Techniques and Surgical Research, Department of Surgery, Medical and Health Science Center, University of Debrecen, Debrecen, Hungary. Conducting experiment, evaluating results and manuscript writing.

${ }^{\mathrm{xI}} \mathrm{MD}$, PhD, CSc, Full Professor, Head of the Department, Department of Operative Techniques and Surgical Research, Department of Surgery, Medical and Health Science Center, University of Debrecen, Debrecen, Hungary. Conducting experiment, evaluating results and manuscript writing.

\section{ABSTRACT}

PURPOSE: To examine the possible late complications of splenectomy or spleen autotransplantation in large laboratory animal model, in which we need non-invasive or minimal-invasive methods for long-term monitoring of the experimental animals.

METHODS: Experimental groups of beagle dogs were: non-operated control, sham-operated control, splenectomy, spleen autotransplantation with 5 or 10 spleen-chips taken into the greater omentum (Furka's technique). Prior to operations, on the $1^{\text {st }}$ postoperative week, monthly till the $6^{\text {th }}$ as well as in the $9^{\text {th }}$ and $12^{\text {th }}$ month, hemorheological examinations were performed. In postoperative $12^{\text {th }}$ month colloid scintigraphy and diagnostic laparoscopy were carried out. At the end of the investigation comparative morphological examinations were performed, too.

RESULTS: From the $4^{\text {th }}-5^{\text {th }}$ postoperative month filtration function of spleen-autotransplants showed particular restoration compared to splenectomy group. However, the functional results did not reach the values of the control or sham-operated groups. Sham-operated control's scintigraphy nicely showed activity in the spleen. In spleen autotransplantation-groups scintigraphy indicated well the activity of spleen-chips. During diagnostic laparoscopy spleen-chips with their blood supply were found. Histologically, the structure of spleenautotransplants was similar to normal splenic tissue.

CONCLUSIONS: The autotransplants are regenerated, their functions have been partly restored, and thus spleen autotransplantation may prevent the possible complications of splenectomy. These parameters and the presented investigative protocol are suitable for longterm following-up of viability of the spleen-autotransplants.

Key words: Splenectomy. Colloids. Radionuclide Imaging. Dogs. 


\section{RESUMO}

OBJETIVO: Examinar as possíveis complicações tardias da esplenectomia ou do autotransplante de baço em modelo animal de grande porte, no qual faz-se necessário o uso de métodos não invasivos ou minimamente invasivos para monitorizar os animais de experimentação.

MÉTODOS: Grupos experimentais de cães beagle foram: não-operados controle, sham-operados controle, esplenectomia, autotransplante de baço com 5 ou 10 fatias de baço colocados no grande omento (técnica de Furka). Antes das operações, na $1^{\text {a }}$ semana de pósoperatório, mensalmente até $6^{\circ}$ assim como no $9^{\circ}$. e $12^{\circ}$. mês, foram realizados exames hemorreológicos. No $12^{\circ}$. mês de pós-operatório, cintilografia colóide e laparoscopia diagnóstica foram realizadas. Ao final do experimento, exames morfológicos comparativos foram realizados também.

RESULTADOS: A partir do $4^{\circ}-5^{\circ}$ mês pós-operatório, a função de filtração dos baços autotransplantados mostraram particular restauração comparados ao grupo esplenectomia. Entretanto, os resultados funcionais não alcançaram os valores dos grupos controle ou sham-operados. A cintilografia dos controles sham-operados mostraram atividade no baço. Nos grupos de autotransplante, a cintilografia indicou bem a atividade das fatias de baço. Durante a laparoscopia diagnóstica, as fatias de baço com seu suprimento sanguíneo foram encontrados. Histologicamente, a estrutura dos autotransplantes de baço foi similar ao tecido normal de baço.

CONCLUSÕES: Os autotransplantes são regenerados, suas funções foram parcialmente restauradas, e então ao autotransplantate esplênico pode prevenir as possíveis complicações da esplenectomia. Estes parâmetros e o protocolo experimental são adequados para o seguimento em longo prazo da viabilidade de autotransplantes esplênicos.

Descritores: Esplenectomia. Colóides. Cintilografia. Cães.

\section{Introduction}

In the ancient times the spleen was considered a "mystic" organ without any function. For today, it has become clear that spleen has complex functions. Its functions can be divided into four main groups, such as filtration, immunological, storage and haemopoietic functions. Recent studies have showed its role in lipid-metabolism, too ${ }^{1-6}$.

In the clinical practice the early and late complications following splenectomy have been known for a long time $e^{2,7,8}$, but the explanation for the late complications was given only by recent research on spleen surgery and spleen-sparing operations ${ }^{8}$. Some of the early complications are not specific to splenectomy: for example bleeding, infection, fever, gastrointestinal motility disorders, sterile wound healing disorders, thrombosis, pancreatitis can be concidered as general surgical complications. However, some of the late complications can be related to the loss of splenic functions: decreased serum $\operatorname{IgM}$, presence of abnormal erythrocytes in the blood, leukocytosis, thrombocytosis, Overwhelming Postsplenectomy Infection (OPSI) Syndrome, atherosclerosis, recurrent infections ${ }^{6-8}$.

Nowadays, with the increase in the number of blunt abdominal trauma and splenectomies performed these complications came to the focus. Increased emphasis has been put on the possibility of thromboembolic complications, ischemic anomalies evolving in different organs and dyslipidaemic disorders following splenectomy ${ }^{1,4,6-11}$.
The most dangerous late complication of splenectomy is still the postsplenectomy sepsis. This fulminant sepsis was firstly described by King and Shumacher ${ }^{7}$ published in 1952. In spite of the modern treatment protocols the mortality of OPSI syndrome is still very high ${ }^{2,11,12-15}$.

In the clinical practice the serious complications can be prevented or avoided in ways of immunoprophylaxis, chemoprophylaxis, spleen preserving operations (e.g., spleen resection, spleen autotransplantation), additionally by informing the patients ${ }^{9,10,16}$. Providing the patient with sufficient information is very important in order to let them see the doctor in the early phase of complications, because the early antibiotic treatment may inhibit the development of postsplenectomy sepsis. Unfortunately, the majority of the patients don't realize the possible consequences of splenectomy.

The maintenance of splenectomized and spleenautotransplantated patients is further complicated by the fact that asplenic and hyposplenic states cannot be indicated with laboratory tests. This difficulty exists because there's no elaborated diagnostic protocol for these aims ${ }^{12,17-20}$.

Since late complications of splenectomy are not examined completely it is required to perform a long-term follow-up study. It would require further surgical research, choosing an appropriate large animal model and defining long-survival experimental period with non-invasive and minimal-invasive investigative protocols.

In our work the aim was to set examining methods that meet these requirements and make possible the long-term follow- 
up of spleen autotransplants performed by "Furka's spleen chip” technique ${ }^{21-23}$, and comparing them to splenectomised, shamoperated and non-operated controls in a beagle canine study.

\section{Methods}

The experiments were approved and registered by the University of Debrecen Committee of Animal Research (permission Nr.: 12/2003. UD CAR), in accordance with the relevant Hungarian Animal Protection Act (Law XVIII/1998) and EU directives.

Fifteen adult male and female beagle dogs (body weight: $9.98 \pm 1.67 \mathrm{~kg}$ ) were involved to in this study. The animals were kept in standard individual cages and maintained on standard diet with free access to water. Free moving was allowed on demand of the animals.

\section{Experimental groups and surgical techniques}

All the surgical interventions were performed in general narcosis with intramuscular ketamine $\left(10 \mathrm{mg} / \mathrm{kg}\right.$, SBH Ketamin ${ }^{\circledR}$, Produlab Pharma B.V., The Netherlands) and xylazine $(0.1 \mathrm{mg} /$ kg, Primazin ${ }^{\circledR}$, Alfasan International B.V., The Netherlands) combination.

The experimental animals were divided into five groups with the following interventions:

I. Non-operated control” (C) group: there was no surgical intervention.

II. Sham-operated control” (SH) group: performed median laparotomy and closure of abdominal cavity in two layers.

III. Splenectomy” (SE) group: after the upper median laparotomy, the whole spleen was removed, the abdominal wall was closed in two layers.

IV-V. Autotransplantation” (AU5 and AU10) group: autotransplantation with 5 or 10 spleen-chips using "Furka's spleen-chip" technique ${ }^{21-23}$ following splenectomy and closure of abdominal cavity in two layers.

The aim of the "Furka's spleen chip technique" is the following: from the removed and healthy spleen parenchyma 5 or 10 chips were made (thickness: $2 \mathrm{~mm}$, length: $20 \mathrm{~mm}$, width: $10 \mathrm{~mm})^{17}$. These chips were rinsed in room temperature physiological salt solution and then the chips were placed between the well vascularised layers of the greater omentum without any fixation. The omentum was closed with 3/0 non-absorbable coated polyester (Ethibond, Ethicon, Inc., Germany) suture materials ${ }^{21-23}$. 3/0 non-absorbable coated polyester (Ethibond, Ethicon,
Inc., Germany) was used for ligature during splenectomy, 0 nonabsorbable polyamide (Ethilon, Ethicon, Inc., Germany) was used for closing the muscle and peritoneum layers. To close the skin 3/0 absorbable polyglactin 910 (Vicryl, Ethicon, Inc., Germany) was used, to avoid causing additional discomfort for the animals during the procedure of stitch removing.

\section{Laboratory investigations}

After overnight fasting, venous blood samples were obtained in the morning by venipuncture of the cephalic vein from all of the animals one day prior the operations, in the postoperative $1^{\text {st }}$ week, monthly till the $6^{\text {th }}$, as well as in the $9^{\text {th }}$ and $12^{\text {th }}$ month for complex hematological, hemostaseological, hemorheological, immunological examinations.

\section{Testing red blood cell deformability}

Among thehemorheologicalparameters, the deformability of the erythrocytes was determined from heparinized blood (sodium-heparin, 143 IU) using a Carat FT-1 filtrometer (Carat Ltd., Hungary) based on St. George's filtration method ${ }^{24}$. From the blood samples 5\% red blood cell - PBS suspensions (osmolarity: $295 \pm 5$ mOsm/kg; pH: 7.4) were prepared and filtrated through $5 \mu \mathrm{m}$ pore-sized polycarbonate filters (Nucleopore ${ }^{\circledR}$, Whatman International Ltd., U.K.), at constant filtration pressure $\left(4 \mathrm{cmH}_{2} \mathrm{O}\right)$. From the filtration profile the interfaced computer calculates the initial filtration rate (IRFR) and the relative cell transit time (RCTT) parameters according to the following formula:

$$
\text { RCTT } \left.=\left(\mathrm{IRFR}^{-1}-1\right) / \mathrm{Hct}\right)+1
$$

where Hct is the hematocrit of the suspension. Measurements were carried out at room temperature $\left(22 \pm 1^{\circ} \mathrm{C}\right)$.

RCTT was used to describe the filtration function of the spleen in our study. Increase of RCTT reflects impaired red blood cell deformability.

\section{Colloid scintigraphy}

In the $12^{\text {th }}$ postoperative month colloid scintigraphy was performed on 3 animals: one in sham-operated and spleen autotransplanted animals with 5 or 10 spleen-chips. $80-110 \mathrm{MBq}$ ${ }^{99 m}$ Tc labeled sodium phytate $\left(\right.$ FYTON $^{\circledR}$, Institute of Isotopes, Budapest, Hungary) was administrated via the cephalic vein under general narcosis. After 20 minutes, SPECT acquisition was started by a Cardio-C gamma camera (Mediso Ltd., Hungary) in "step and shoot” mode with 3 degrees steps. The colloid was phagocytized by the cells of the reticulo-endothelial system; therefore increased activity was expected in the liver and spleen as well as in the spleen autotransplants ${ }^{25}$. The reconstructed distribution was presented in 
"browser view": visualizing the transaxial, sagittal and coronal slices through a selected 3-D point.

\section{Diagnostic laparoscopy}

In the $12^{\text {th }}$ postoperative month diagnostic laparoscopy was performed on the same animals, which were underwent to the scintigraphic investigations. Under general anaesthesia the Veresneedle was insert into the abdominal cavity under the sternal process, because of the possible adhesions and the gothic rib wault. After completing of pneumoperitoneum (intraabdominal pressure: $13 \mathrm{Hgmm}$ ), the optic system was inserted through a 10 mm port. If it was necessary, a Maryland grasper was also inserted through a second 5-mm size port, at the medioclavicular line. Video records were made during the operations. We observed the abdominal state to identify the spleen autotransplants and to check the possible adhesions.

\section{Histological investigation}

Comparative histological investigations were performed on the removed spleens of the splenectomy group and in the $12^{\text {th }}$ postoperative month -at the end of the investigation- on the spleenautotransplants.

The anesthetized animals were euthanatized with intracardially administrated potassium-chloride solution (2 mmol/ $\mathrm{kg}$ ) and the spleen-autotransplants were removed. The material was fixed in 4\% formalin, dehydrated in graded series alcohol, embedded in paraffin, microtomed into $5 \mu \mathrm{m}$ step sections and stained with hematoxilin and eosin, for light microscopy investigation.

\section{Statistical analysis}

The numerical data was presented in the form mean \pm S.D. Although the case number was low, for an orientational comparison Mann-Whitney U-test and one-way ANOVA on ranks tests were used, with a level of significance of $p<0.05$.

\section{Results}

All of the experimental animals survived the operations and there was no death during the 12-month postoperative followup period. No surgical complication -neither early, nor late- was detected.

\section{Changes in erythrocyte deformability}

The changes in the relative cell transit time (RCTT) in the function of time are presented on Figure 1.

After the interventions the relative cell transit time increased in every operated group. In the first half of the investigative period -till the $4^{\text {th }}$ postoperative month- there was no considerable difference between the groups.

In the $5^{\text {th }}$ postoperative month, there was significant difference between the values of the spleen autotransplantation groups (AU5 and AU10) compared to base. From the $6^{\text {th }}$ postoperative month we observed that the values of the spleen autotransplantation with 10 spleen chips group (AU10) were lower than the values in the splenectomy group. It converged to the level of the sham- and non-operated control groups.

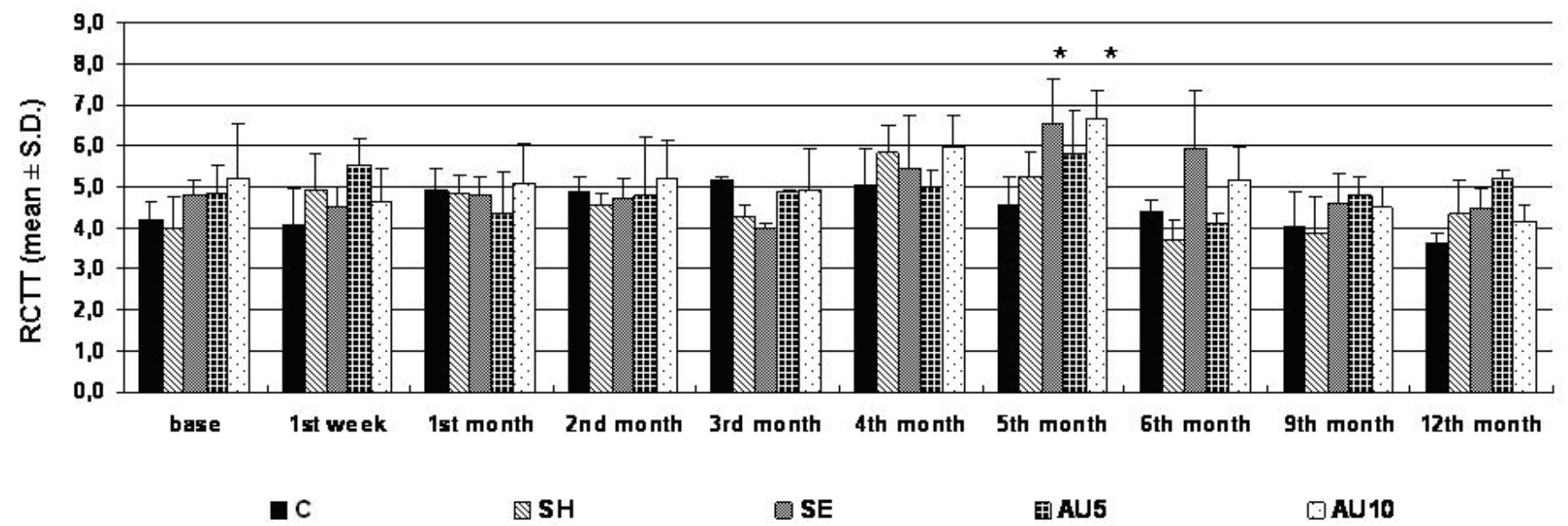

FIGURE 1 - The changes in the relative cell transit time (RCTT) the function of time.

C: non-operated control, SH: sham operated control, SE: splenectomy, AU5: autotransplantation with 5 spleen chips, AU10: autotransplantation with 10 spleen chips,

$* \mathrm{p}<0.05$ vs. base 


\section{Colloid scintigraphy investigations}

The colloid scintigram of the sham-operated control animal showed the highest activity in the liver. The spleen accumulated low activity in the usual anatomical location (Figure 2A).

In the experimental animal, which underwent to spleen autotransplantation of five spleen chips, there was no activity accumulation in the spleen transplants, only in the parenchyma of the liver.

The scintigram of the experimental animal with 10 autotransplanted spleen chips also showed the highest activity in the liver. However, focal increased activity accumulation could be visualized corresponding to the reticuloendothelial cells in the spleen autotransplants (Figure 2B).
A

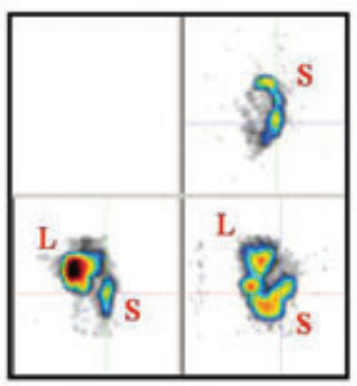

B

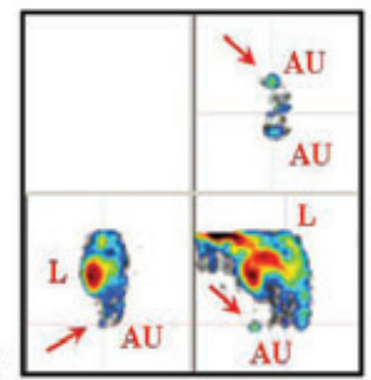

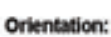
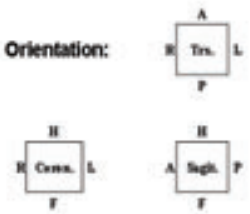

FIGURE 2 - Colloid scintigraphy in sham-operated control animal (L=liver, S=spleen) (A) and in autotransplanted animal with 10 spleen chips (B) in the $12^{\text {th }}$ postoperative month, demonstrated by selected images (L=liver, $\mathrm{AU}=$ spleen autotransplants). The arrows show to the spot-like enhancement to the spleen autotransplants.

\section{Diagnostic laparoscopy}

The diagnostic laparoscopy in the sham-operated control animal showed well the spleen in average size, and being situated in the usual anatomical position. There was no considerable adhesion in the abdominal cavity.

In the 5 spleen chips autotransplanted animal (AU5) the diagnostic laparoscopy found some of the spleen autotransplants between the layers of the omentum. In the abdominal cavity there were no several adhesions, like in the previous group (Figure 3A).

In the animal that underwent autotransplantation with 10 spleen chips (AU10), all of the replanted spleen chips were found on the video during the diagnostic laparoscopy. The own blood supply of the autotransplants were observed. We found no significant adhesion in this case, too (Figure 3B).
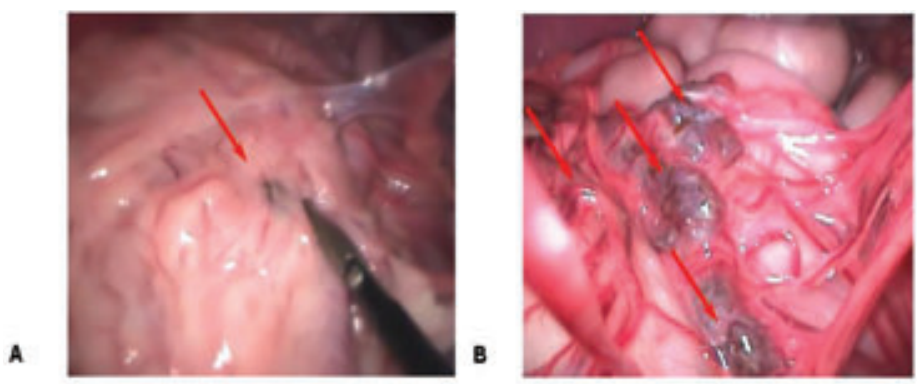

FIGURE 3 - Images from the video records made during the diagnostic laparoscopy of 5-spleen-chip autotransplanted animal (A), 10-spleen-chip autotransplanted animal $(\mathbf{B})$ in the postoperative $12^{\text {th }}$ month. The arrows show to the spleen autotransplants.

\section{Histological investigations}

Figure 4 shows the pictures of the histological investigations of removed and intact spleen with normal follicular and trabecular structure. The other presented material was taken from 10 spleen chips autotransplanted animal (AU10). On the section of the autotransplants well formed follicules, slightly hemorrhaged red pulp and little disorganized trabecular structure were seen.

A
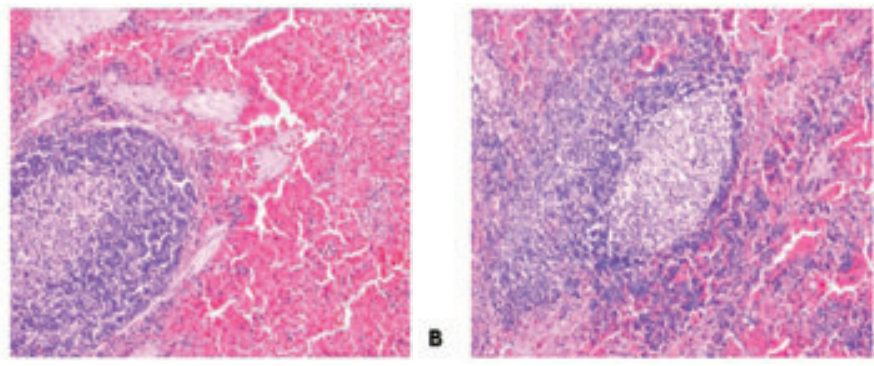

FIGURE 4 - Sections made from the removed intact spleen (A) and the regenerated spleen autotransplants $(\mathbf{B})$ at the end of the 12-month followup period.

Staining: hematoxilin and eosin, M: 200X.

\section{Discussion}

Despite of the modern chemo- and immunoprophylaxis, the possible complications of splenectomy are still a great problem $^{2,11-13}$. Spleen preserving methods play an important role in preventing these complications. In the current experiment -joining to the spleen saving investigations performed over 20 years-, we examined the viability of implanted spleen-chips during one postoperative year with morphological and functional methods on inbred beagle dogs $\mathrm{s}^{11,14,17,19,21-23}$.

Erythrocyte deformability can be an informative laboratory parameter, being indicative for decreased or lost splenic filtration function besides the functional scintigraphy ${ }^{19,26}$. Our results suggest that the spleen-autotransplants are viable, their functions 
have been partly restored and thus spleen autotransplantation may contribute to preventing the possible complications of splenectomy, as supported by other studies ${ }^{14,17,18,26-31}$.

Relative cell transit time of red blood cells was measured by filtrometry ${ }^{24}$. This parameter is inversely proportional to the deformability of the red blood cells: when the RCTT increases, the deformability is decreased. The change of this parameter is indicative for the filtration function of the $\operatorname{spleen}^{26}$. In the $1^{\text {st }}$ postoperative week relative cell transit time increased in the operated groups contrary base values, induced by the rheological changes following the surgical interventions (acute phase reaction).

During the first half postoperative year there were no remarkable differences between experimental groups, because the regeneration of the splenic tissue starts between the $4^{\text {th }}-6^{\text {th }}$ postoperative months ${ }^{17,19}$. From the $5^{\text {th }}$ postoperative month, the values of the 10-spleen-chip autotransplantation group were lower than the values of the splenectomy group, converging to the control groups. The high values in the autotransplantation with 5 spleen chips group could be related to the fact that not all of the spleen transplants were found in these experimental animals. They were supposedly in "functional hyposplenic state" at that time ${ }^{17,26}$.

Scintigraphy in the sham-operated control animal clearly showed the spleen. During diagnostic laparoscopy we orientated about the possible adhesions caused by the opening and closing of the abdomen.

There was no splenic radiopharmaceutical accumulation in the animal autotransplanted with 5 spleen chips, in agreement with the result of laparoscopy where we could not find all of the implanted spleen chips. Another reason can be a possible "sleeping" state of the spleen autotransplants in this animal, resulting in a hyposplenic condition at the time of scintigraphy ${ }^{17}$.

In the animal autotransplanted with 10 spleen chips the scintigraphy showed activity in the region of the greater omentum, confirming the phagocytic function of the autotransplants. During diagnostic laparoscopy we found all of the transplants. These findings confirm the viability of the spleen chips in this animal.

The histological analysis showed obvious similarity between the structure of the transplants and intact splenic tissue to demonstrate the viability and the regeneration of the implanted spleen chips.

Although not all of the spleen chips were found in the autotransplantation with 5 spleen chips group, the previous investigation of our Department did not find correlation between the number of the implanted spleen chips and their viability ${ }^{14,19}$.

Our results suggest the spleen autotransplants -taken into greater omentum by Furka's technique- are viable. The presented non-invasive or minimally invasive investigative protocol did not cause significant strain or pain in the experimental animals, therefore it was suitable for the long-term follow-up. Our data showed a partial restoration in the function of the spleen autotransplants and thus, it is suggested, that spleen autotransplantation may prevent the possible complications of splenectomy.

Besides functional scintigraphy, erythrocyte deformability can be indicative factor for the possible decrease (functional hyposplenia) or lost (asplenia) of splenic functions. These investigative methods allow to design and to carry out longterm follow-up, which may help to observe effectively the long time complications after splenectomy or spleen autotransplantation. These results may contribute to investigate the formation of the complication and to develop indicative examination protocols for the clinical practice.

In the future experiments we wish to increase the case number in order to achieve more precise statistical analysis. Our other purpose is to adapt human scintigraphic examination methods to beagle dogs. The first advantage of that investigation method is that to make it easier to avoid the problems caused by the overlapping of liver and spleen-chips. These problems encumber the precise image analysis. The other advantage is to provide information not only about the morphological state, but about the splenic functions - specially filtration function- too. For this aim, we plan to use more sophisticated hemorheological method, the ektacytometry, to test red blood cell deformability in parallel with the bulk filtration method. Also, we plan to study the difference between spleen resections at different rates considering the quantity of autotransplanted splenic mass. Thus, our investigations must be extended with partial and subtotal spleen resection groups.

\section{Conclusions}

Our results suggest that autotransplants are regenerated, their functions have been partly restored, and thus spleen autotransplantation may prevent the possible complications of splenectomy. Besides functional scintigraphy, erythrocyte deformability can be indicative for functional hyposplenia or asplenia. These parameters are suitable for long-term investigation to follow the spleen autotransplants.

\section{References}

1. Akan AA, Sengül N, Simsek S, Demirer S. The effects of splenectomy and splenic autotransplantation on plasma lipid levels. J Invest Surg. 2008;21:369-72.

2. Hansen K, Singer DB. Asplenic-hyposplenic overwhelming sepsis: 
postsplenectomy sepsis revisited. Pediatr Dev Pathol. 2001;4:10521.

3. Lochwood CM. Immunological functions of the spleen. Clin Haematol. 1983;12:449-65.

4. Petroianu A, Veloso DF, Alberti LR, de Souza Vasconcellos L. Plasma lipid alterations after total splenectomy, subtotal splenectomy and splenic auto-implants in rats. J Gastroenterol Hepatol. 2008;23:2214.

5. Timens W, Leemans R. Splenic autotransplantation and the immune system. Adequate testing required for evaluation of effect. Ann Surg. 1992;215:256-60.

6. Witztum JL. Splenic immunity and atherosclerosis: a glimpse into a novel paradigm? J Clin Invest. 2002;109:721-4.

7. King H, Schumacher HB. Splenic studies. I. Susceptibility to infection after splenectomy performed in infancy. Ann Surg. 1952;136:239-42.

8. Harbrecht BG. Is anything new is adult splenic trauma? Am J Surg. 2005;190:273-8.

9. Acs G, Furka I, Miko I, Szendroi T, Hajdu Z, Sipka S Jr, Barath S, Aleksza M, Csipo I, Balo E, Balint A, Fekete K. [Comparative hematologic and immunologic studies of patients with splenectomy and spleen autotransplantation. Magy Seb. 2005;58:74-9.

10. Benoist S. Median and long-term complications of splenectomy. Ann Chir. 2000;125:317-24.

11. Furka I, Hajdu Z, Miko I, Szendroi Z, Barnak G, Bokk A. Spleen autotransplantation. Experimental and Clinical Experiences. In: 23th World Congress of the International College of Surgeon, Monduzzi Editore, Bologna, 1992. p. 907-12.

12. Bridgen ML. Overwhelming postsplenectomy infection - still a problem. West J Med. 1992;147:440-3.

13. Lynch AM, Kapila R. Overwhelming postsplenectomy infection. Infect Dis Clin North Am. 1996;10:693-707.

14. Miko I, Serfozo J, Kappelmayer J, Sipka S, Furka A, Imre S, Galuska L, Kovacs J, Brath E, Peto K, Nemeth N, Furka I. Can the injured spleen be preserved? Results of 20-year experiments. Magy Seb. 2005;58:69-73.

15. Taylor MD, Genuit T, Napolitano LM. Overwhelming postsplenectomy sepsis and trauma: time to consider revaccination? J Trauma. 2005;59:1482-5.

16. Shatz DV. Vaccination practicles among North American Trauma Surgeons in splenectomy for trauma. J Trauma. 2002;5:950-6.

17. Miko I, Furka I, Serfozo J, Joos Gy, Telek B, Matesz K, Hauck M, Bekesi L, Ignath T. Comparative Study of Haematological and MicroMorphological Results in Long-Surviving Spleen Autotransplants. In: Chirurgische Forschung, ed: S. Uranüs, Zuckschwerdt Verlag, München - Bern - Wien - New York 1994. p.50-5.

18. Miko I, Brath E, Furka I, Kovacs J, Kelvin D, Zhong R. Spleen autotransplantation in mice: a novel experimental model for immunology study. Microsurgery. 2001;21:140-2.

19. Miko I, Brath E, Nemeth N, Furka A, Sipka S Jr, Peto K, Serfozo J, Kovacs J, Imre S, Benko I, Galuska L, Sipka S, Acs G, Furka I. Spleen autotransplantation. Morphological and functional followup after spleen autotransplantation in mice: a research summary. Microsurgery. 2007;27:312-6.

20. Brigden ML. Detection, education and management of the asplenic or hypospenic patient. Am Fam Physician. 2001;63:499-508.

21. Furka I, Miko I, Papp L, Miko T. Salvaging the spleen by experimental resection or organtransplantation. In: Jubileuszowy Zjazd Towarzystwa Chirurgów Polskich, vol. 2, Krakow 1989. p.453-6.

22. Furka I, Miko I, Tasoly E. Heterotopicseszkaja autotranszplantacija szelezenki v ekszperimente. Heterotopic spleen autotransplantation in experiment. Khirurgija. 1989;9:125-7.
23. Furka I, Miko I, Serfozo J, Frendl I, Hauck M. Autotransplantation of the spleen. In: Second World Week of Professional Updating in Surgery and in Surgical and Oncological Disciplines of the University of Milan, Lecture Book Vol. II., Milan, ed. Monduzzi, Bologna, 1990;767-9.

24. Dormandy J, Flute P, Matrai A, Bogar L, Mikita J. The new St. George’s blood filtrometer. Clin Hemorheol. 1985;5:975-9.

25. Galuska L. Spleen inferior to the liver: an unusual developmental disorder. Clin Nucl Med. 2000;25:944-5.

26. Miko I, Nemeth N, Sipka S Jr, Brath E, Peto K, Gulyas A, Furka I, Zhong R. Hemorheological follow-up after splenectomy and spleen autotransplantation in mice. Microsurgery. 2006;26:38-42.

27. Resende V, Petroianu A, Junior WC. Autotransplantation for treatment of severe splenic lesions. Emerg Radiol. 2002;4:208-12.

28. Resende V, Petroianu A. Functions of the splenic remnant after subtotal splenectomy for treatment of severe splenic injuries. Am J Surg. 2003;185:311-5.

29. de Souza JC, Athie E, Marigo C, Rahal F, Fagundes DJ. Autologous and heterotopic splenic regeneration in rats. Acta Cir Bras. 2005;20:253-57.

30. Simoes FC, Marques RG, Diestel CF, Caetano CE, Dinis AP, Horst NL, Nogueira Neto JF, Portela MC. Lipidic profile among rats submitted to total splenectomy isolated or combined with splenic autotransplant. Acta Cir Bras. 2007;22(Suppl 1):46-51.

31. Malago R, Reis NS, Araujo MR, Andreollo NA. Late histological aspects of spleen autologous transplantation in rats. Acta Cir Bras. 2008;23:274-81.

\section{Acknowledgment}

We express our thanking to our collaborating partners for their invaluable contribution.

\section{Correspondence:}

Erika Sajtos

Department of Operative Techniques and Surgical Research Medical and Health Science Center

University of Debrecen

H-4032 Debrecen, Nagyerdei krt. 98., P.O.Box: 21., Hungary

Phone/Fax: +36-52-416-915

sajtos.erika@gmail.com

Received: September 21, 2011

Review: November 23, 2011

Accepted: December 20, 2011

Conflict of interest: none

Financial sources: The Hungarian Scientific Research Fund (Grant number: OTKA T049331) and The Hungarian Ministry of Health, Medical Research Council (Grant number: ETT 387/2006.)

${ }^{1}$ Research performed at the Department of Operative Techniques and Surgical Research, Department of Surgery, Medical and Health Science Center, University of Debrecen, Hungary. 